\title{
Prevalence of musculoskeletal pain in adolescents and its association with the use of electronic devices*
}

\author{
Prevalência de dor musculoesquelética em adolescentes e sua associação com o uso de \\ dispositivos eletrônicos
}

Ingrid Becker Saueressig ${ }^{1}$, Valéria Mayaly Alves de Oliveira ${ }^{1}$, Michelle Katherine Andrade Xavier ${ }^{1}$, Luan Ricardo Alves dos Santos ${ }^{1}$, Kelvin Mikael Araújo Silva1, Rodrigo Cappato de Araújo ${ }^{1}$

${ }^{*}$ Received from University of Pernambuco, Petrolina, PE, Brazil.

DOI 10.5935/1806-0013.20150025

\section{ABSTRACT}

BACKGROUND AND OBJECTIVES: The use of electronic devices has reconfigured the daily life of adolescents; however, their excessive use may be associated to health problems. This study aimed at observing the prevalence of musculoskeletal pain among adolescents and its association with the use of computers and videogames. METHODS: Sample was made up of 265 adolescents of both genders (14 to 19 years old), students of a public school, who have answered a questionnaire about the use of electronic devices, musculoskeletal pain, physical activity and demographics. Values of absolute and relative frequency, confidence intervals and mean and standard deviation were expressed for descriptive analysis. Independent $t$ and Chi-square tests were used for comparison between genders, and multiple logistic regression model was used for association test. All tests had significance level of 5\%.

RESULTS: The prevalence of musculoskeletal pain was $72.1 \%$, being significantly higher for females. There has been no association between musculoskeletal pain and the use of electronic devices; however it was identified that females had 10.66 times more probability of reporting this type of pain. Cervical and thoraco-lumbar pains were associated to females $(\mathrm{OR}=1.80)$, and individuals attending the $2^{\text {nd }}$ and $3^{\text {rd }}$ year were associated to cervical pain $(\mathrm{OR} \geq 2.26)$.

CONCLUSION: There has been high prevalence of musculoskeletal pain among adolescents, especially females. Although not observing association between pain and use of electronic devices, it was noted that those attending the last years of high school and of the female gender had higher risk to develop musculoskeletal pain. Keywords: Adolescent, Computer, Musculoskeletal pain, Technology, Videogames.

1. University of Pernambuco, Petrolina, PE, Brazil.

Submitted in March 10, 2015.

Accepted for publication in May 04, 2015.

Conflict of interests: none - Sponsoring sources: none.

Correspondence to:

Rodrigo Cappato de Araújo

BR $408 \mathrm{~km} 2 \mathrm{~S} / \mathrm{N}$ - Cidade Universitária

56328-903 Petrolina, PE, Brasil.

E-mail: rodrigo.cappato@upe.br

(C) Sociedade Brasileira para o Estudo da Dor

\section{RESUMO}

JUSTIFICATIVA E OBJETIVOS: O uso de dispositivos eletrônicos reconfigurou o cotidiano dos adolescentes, porém a utilização excessiva pode estar associada a problemas de saúde. O objetivo deste estudo foi verificar a prevalência de dor musculoesquelética em adolescentes e sua associação com o uso de computador e jogos eletrônicos.

MÉTODOS: A amostra foi composta por 265 adolescentes de ambos os gêneros (14 a 19 anos), estudantes de uma escola pública, que responderam um questionário sobre uso de dispositivos eletrônicos, dor musculoesquelética, atividade física e dados sócio-demográficos. Para análise descritiva, foram expressos valores de frequência absoluta, relativa, intervalos de confiança e média e desvio padrão. Foram utilizados o teste $\mathrm{t}$ independente e Qui-quadrado para comparação entre gêneros, e modelo de regressão logística múltipla para teste de associação. Todos os testes tiveram nível de significância de $5 \%$.

RESULTADOS: A prevalência de dor musculoesquelética foi de $72,1 \%$, sendo significativamente maior no gênero feminino. Não foi encontrada associação entre dor musculoesquelética e uso de dispositivos eletrônicos. Porém, foi identificado que o gênero feminino apresenta 10,66 mais probabilidades de referir esse tipo de dor. As dores cervicais e toracolombares tiveram associação com gênero feminino $(\mathrm{OR}=1,80)$ e os indivíduos que cursam o $2^{\circ}$ e $3^{\circ}$ ano tiveram associação com dor cervical $(\mathrm{OR} \geq 2,26)$.

CONCLUSÁO: Evidenciou-se alta prevalência de dor musculoesquelética nos adolescentes, principalmente do gênero feminino. Embora não se tenha observado associação entre dor e uso de dispositivos eletrônicos, notou-se que aqueles que cursam os últimos anos do ensino médio e do gênero feminino apresentam maior risco de desenvolver dores musculoesqueléticas.

Descritores: Adolescente, Computador, Dor musculoesquelética, Jogos de vídeo, Tecnologia.

\section{INTRODUCTION}

Recent technological development has increased and made easier personal access to electronic devices. The use of such devices (computers, tablets, cell phones and videogames) is changing the daily routine of adolescents and becoming a central part of their lives, be it for socialization, entertainment, learning or working, enhancing adolescents' interest $\mathrm{t}^{1-3}$. 
It is claimed that expressive technological development, added to Brazilian economic growth, is increasing the excessive use of such devices by adolescents. In addition, digital inclusion programs might have possibly increased time spent with such technologies ${ }^{2}$. In 2012, one such program was implemented by the State Department of Education of Pernambuco, which has distributed tablets or notebooks for high school students, aiming at making easier the access to such communication media. However, the abusive use may generate mental overload, excess weight, sedentary habits, musculoskeletal pain and decreased sleep duration, inducing aggressiveness, irritability and tiredness symptoms among adolescents. Inadequate postures for a long time, commonly adopted during the use of the devices, may justify the presence of some of these symptoms ${ }^{3-8}$.

In Brazil, the only study to evidence association between excessive computer use and musculoskeletal pain was carried out in 2003 and has not found such association ${ }^{9}$. More recent studies carried out in developed countries ${ }^{10-12}$ have found association and with this it is possible to infer that the temporal factor, added to socioeconomic and technological development, may influence such results.

So, this study aimed at determining the prevalence of musculoskeletal pain among adolescents of a public school and its association with the use of computer and videogames.

\section{METHODS}

This is a descriptive, correlational and crossover study carried out in the Application School Professor Vande de Souza Ferreira, Petrolina. Sample was made up of 262 adolescents of both genders. For sample calculation with the WinPepi program $^{13}$, we considered the school population $(n=600)$, bilateral statistics with $\alpha=0.05$, power of $80 \%$, estimated proportion of $50 \%, 5 \%$ error and sample loss of $10 \%$.

Inclusion criteria were students aged from 14 to 19 years, with duly dated Free and Informed Consent Term (FICT) signed by them or their guardians, when minors. Exclusion criteria were adolescents with some mental or cognitive impairment to answer the questionnaire, physical disability preventing or compromising measurements, and also pregnant women, in addition to students with musculoskeletal pain or injuries due to recent infectious onco-hematologic, genetic and traumatic diseases.

The questionnaire had questions to evaluate the following variables: age, gender, school grade attended, paid activity, family income in minimum wages, use of computer and videogames, presence of musculoskeletal pain and physical activity level. For such, 46 questions of the self-applicable questionnaire Musculoskeletal syndromes and injuries in children and adolescents and their relationship with computer and videogames and a drawing representing the human body to locate pain, according to Jannini et al. ${ }^{14}$, were used. This tool includes aspects of musculoskeletal painful symptoms present in the last three months and questions related to the use of computers and videogames. Some questions were adapted to help study understanding and scope, replacing laptop and videogames by Notebook/Tablet and electronic games, respectively.
Regarding the use of computers, use of computer (types), home availability, own device, age when started using, use frequency (Monday to Friday and weekends) and activities performed with the device were evaluated. With regard to videogames, the following were evaluated: use of games, home availability, own device, use frequency and time (Monday to Friday, Saturday and Sunday), use the day before the study and use time.

With regard to painful symptoms, the questionnaire has evaluated: onset time, periodicity, duration and time, modular and triggering factors, sensory features, interference on daily activities, use of analgesics, site, and intensity evaluation by the 10-point numeric visual scale. Answers to the International Physical Activity Questionnaire (IPAQ) - Short Ver$\operatorname{sion}^{15}$ were used to evaluate the level of physical activity.

Portable electronic scale (Camry) and portable stadiometer (Welmy) were used to collect body mass index (BMI) and height, respectively, according to International Society for the Advance of Kinanthropometry (ISAK) standardization ${ }^{16}$. Individuals' classification by IMC has followed criteria suggested by Cole et al. ${ }^{17}$.

\section{Statistical analysis}

Independent variables gender, age, socioeconomic level, professional activity, physical activity level, nutritional status, time using computers, time using videogames and total device use time, and the dependent variable presence of pain were considered. To differentiate pain sites, its presence in cervical, shoulder girdle and thoracolumbar regions, and in upper and lower limbs was considered.

Data were tabulated in the Microsoft Excel program by double data entry. Statistical program SPSS (version 20) was used for data analysis. Distribution of relative and absolute frequency of categorical variables and confidence interval (CI 95\%) for proportions were used for descriptive analysis. Mean and standard deviation were calculated for numerical variables.

For inferential analysis, Kolgomorov-Sminorv test was used for data distribution analysis, Pearson Chi-square test was used to check possible associations between two variables and independent $t$ test was used to analyze difference between genders. Multiple logistic regression was used to express the level of association among variables, through odds ratio estimate (Odds Ratio=OR) and confidence interval of $95 \%$. Such analysis has allowed the observation of model variables and the exploration of confounding factors, identifying possible need for analysis adjustment. It is worth mentioning that only variables with $\mathrm{p}<0.20$ in regression were part of the final multiple model. Hosmer-Lemeshow value has described the explanatory power of the final model. Statistical significance was $\mathrm{p}<0.05$.

The study was approved by the Research and Ethics Committee UPE CAAE: 13598313.5.0000.5207.

\section{RESULTS}

Participated in the study 262 adolescents, aged between 14 and 19 years. Socio-demographic and anthropometric features, 
nutritional status, physical and professional activity level are presented in Table 1. In comparing genders, male adolescents had higher height, BMI and physical activity level (Table 1). With regard to the use of devices, mean computer use time was 228.75 min per week and $3.83 \mathrm{~h}$ per day; while for videogames, mean was 52.07 min per week and $3.83 \mathrm{~h}$ per day. Mean total time was $4.69 \mathrm{~h}$.

In comparing between genders, there has been no statistically significant difference in computer use $(\mathrm{p}=0.947)$. However boys used videogames for a longer period $(\mathrm{p}=0.001)$ and had longer total time $(\mathrm{p}=0.007)$ (Figure 1).

Data regarding musculoskeletal complaints are shown in table 2. Girls had more painful complaints, especially in the thoracolumbar region, and tiredness sensation at wake-time and during the day. In addition, they have reported more use of analgesics (Table 2).

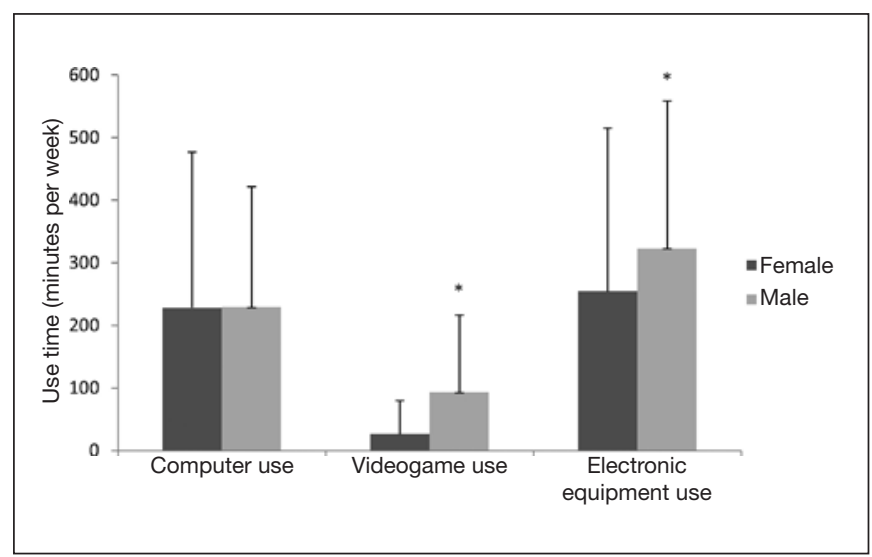

Figure 1. Comparison between genders of computer and videogame use time and total time in minutes per week

${ }^{*} \mathrm{p}<0.05$.

Table 1. Socio-demographic, anthropometric features, nutritional status, physical and professional activity level of adolescents, stratified by gender

\begin{tabular}{|c|c|c|c|c|}
\hline Variables & $\begin{array}{c}\text { Total } \\
(\mathrm{n}=262)\end{array}$ & $\begin{array}{c}\text { Male } \\
(n=101)\end{array}$ & $\begin{array}{l}\text { Female } \\
(\mathrm{n}=161)\end{array}$ & $p$ value \\
\hline Body mass index* & $56.61 \pm 11.21$ & $58.91 \pm 10.93$ & $55.16 \pm 11.18$ & 0.001 \\
\hline \multicolumn{5}{|l|}{ Family income } \\
\hline 1 to $2 \mathrm{MW}$ & $120(47.4 \%)$ & $40(40 \%)$ & $80(52.3 \%)$ & \multirow[t]{2}{*}{0.074} \\
\hline Above $2 \mathrm{MW}$ & $133(52.6 \%)$ & $60(60 \%)$ & $73(47.7 \%)$ & \\
\hline Overweight/obesity & $192(73.3 \%)$ & $73(72.3 \%)$ & $119(73.9 \%)$ & 0.882 \\
\hline \multicolumn{5}{|l|}{ Physical activity level } \\
\hline Active & 160 (61.1\%) & 72 (71.3\%) & 88 (54.7\%) & \multirow[t]{2}{*}{$0.011^{*}$} \\
\hline Inactive & $102(38.9 \%)$ & $29(28.7 \%)$ & $73(45.3 \%)$ & \\
\hline \multicolumn{5}{|l|}{ Professional activity } \\
\hline Yes & $90(34.5 \%)$ & 39 (39\%) & $51(31.7 \%)$ & 0.282 \\
\hline
\end{tabular}

$\mathrm{MW}=$ minimum wage; Values in Mean $\pm \mathrm{SD} ;{ }^{* *} \mathrm{p}<0.05$.

Table 2. Absolute and relative frequencies of painful symptoms, tiredness sensation at wake-time and along the day, difficulty to sleep, pain intensity and site in adolescents, stratified by gender

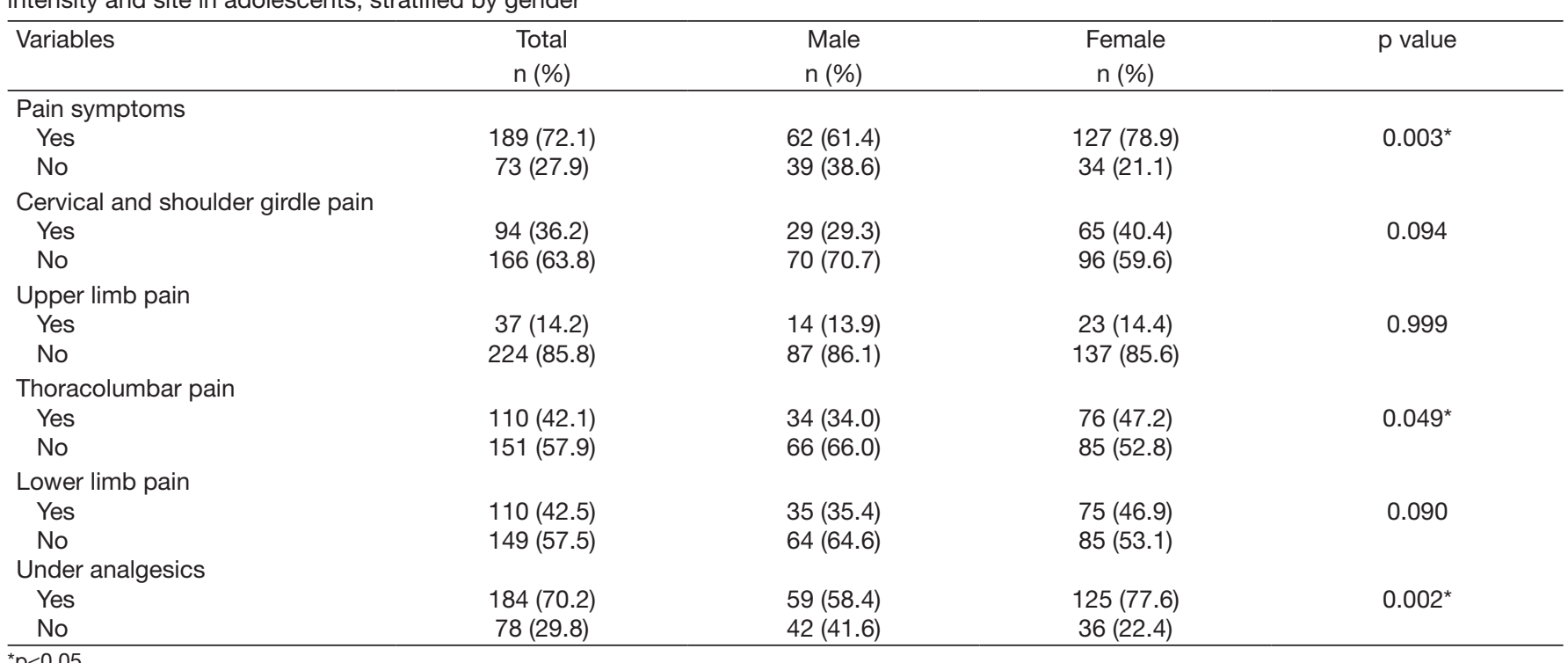


Multiple logistic regression analysis has shown that variables gender and school grade were maintained in the final model, being that females were more likely to have musculoskeletal pain $(\mathrm{p}=0.001)$. However, adolescents of the $8^{\text {th }}$ grade had lower probabilities of complaints $(\mathrm{p}=0.036)$ (Table 3$)$. Hosmer-Lemeshow value was $98 \%$.

With regard to different anatomic regions and painful symptoms, adolescents and students of the second and third year were almost twice more likely to report cervical and shoulder girdle pain $(\mathrm{p}<0.021)$ (Table 4).

For the thoracolumbar region, just the variable gender was kept in the final model, showing that female adolescents are more likely to report pain complaints in this region $(\mathrm{p}=0.035)$ (Table 5).

No association was observed between independent variables and upper and lower limbs pain (Table 6).

Table 3. Association of independent variables and the presence or absence of musculoskeletal pain among adolescents

\begin{tabular}{|c|c|c|c|c|}
\hline Independent variables & $\begin{array}{c}\text { Presence of pain } \\
\mathrm{n}(\%)\end{array}$ & $\begin{array}{c}\text { Absence of pain } \\
n(\%)\end{array}$ & OR [Cl 95\%] & OR Multiple Model [Cl 95\%] \\
\hline \multicolumn{5}{|l|}{ Gender } \\
\hline Female & $127(67.2)$ & $34(46.6)$ & $2.35[1.35-4.08]^{\star}$ & $10.66[1.37-82.62]^{*}$ \\
\hline Male & $62(32.8)$ & $39(53.4)$ & & \\
\hline \multicolumn{5}{|l|}{ Age (years) } \\
\hline 14 to 15 & 97 (51.3) & $38(52.0)$ & $0.97[0.57-1.67]$ & \\
\hline 16 to 19 & $92(48.7)$ & $35(48.0)$ & 1 & \\
\hline \multicolumn{5}{|l|}{ Education } \\
\hline $8^{\text {th }}$ grade & $85(45.2)$ & $41(56.2)$ & $0.78[0.37-1.65]^{*}$ & $0.41[0.23-0.73]^{*}$ \\
\hline $1^{\text {st }}$ year & $23(12.2)$ & $1(1.4)$ & 1 & \\
\hline $2^{\text {nd }}$ year & 55 (29.3) & $16(22.0)$ & $10.82[1.41-83.00]^{*}$ & \\
\hline $3^{\text {rd }}$ year & 25 (13.3) & $15(20.5)$ & $1.59[0.31-3.11]$ & \\
\hline \multicolumn{5}{|l|}{ Socioeconomic level } \\
\hline Up to $2 \mathrm{MW}$ & $91(50.3)$ & $29(40.3)$ & $1.50[0.86-2.61]$ & \\
\hline Above $2 \mathrm{MW}$ & $90(49.7)$ & $43(59.7)$ & 1 & \\
\hline \multicolumn{5}{|l|}{ Professional activity } \\
\hline Works & $66(35.1)$ & 24 (32.9) & $1.11[0.62-1.96]$ & \\
\hline Does not work & $122(64.9)$ & $49(67.1)$ & 1 & \\
\hline \multicolumn{5}{|l|}{ Nutritional status } \\
\hline Overweight/obesity & $133(70.4)$ & $59(80.8)$ & $0.56[0.29-1.09]$ & \\
\hline Eutrophic & $56 \quad(29.6)$ & $14(19.2)$ & 1 & \\
\hline \multicolumn{5}{|l|}{ Physical activity level } \\
\hline Inactive & $74(39.2)$ & $28(38.4)$ & $1.03[0.59-1.80]$ & \\
\hline Active & $115(60.8)$ & $45(61.6)$ & 1 & \\
\hline \multicolumn{5}{|l|}{ Computer use } \\
\hline High time (>3h/day) & $111(58.7)$ & $39(53.4)$ & $1.24[0.72-2.14]$ & \\
\hline Low time (<3h/day) & 78 (41.3) & $34(46.6)$ & 1 & \\
\hline \multicolumn{5}{|l|}{ Videogames use } \\
\hline High time (>1h/day) & $65(34.4)$ & $33(45.2)$ & $0.63[0.37-1.10]$ & \\
\hline Low time $(<1 \mathrm{~h} /$ day $)$ & $124(65.6)$ & $40(54.8)$ & 1 & \\
\hline \multicolumn{5}{|l|}{ Total time } \\
\hline High & $92(48.7)$ & $40(54.8)$ & $0.78[0.45-1.34]$ & \\
\hline Low & 97 (51.3) & $33(45.2)$ & 1 & \\
\hline
\end{tabular}

${ }^{*} \mathrm{p}<0,05 . \mathrm{MW}=$ minimum wage.

Table 4. Association of independent variables and presence and absence o cervical and shoulder girdle pain among adolescents

\begin{tabular}{|c|c|c|c|c|}
\hline Independent variables & $\begin{array}{c}\text { Presence of pain } \\
\mathrm{n}(\%)\end{array}$ & $\begin{array}{c}\text { Absence of pain } \\
n(\%)\end{array}$ & OR [Cl 95\%] & Adusted OR [Cl 95\%] \\
\hline \multicolumn{5}{|l|}{ Gender } \\
\hline Female & 65 (69.1) & $96(57.8)$ & $0.61[0.35-1.04]$ & $1.80[1.02-3.17]^{*}$ \\
\hline Male & $29(30.9)$ & $70(42.2)$ & 1 & \\
\hline \multicolumn{5}{|l|}{ Age (years) } \\
\hline 14 to 15 & $50(50.5)$ & 85 (51.2) & $0.92[0.56-1.53]$ & \\
\hline 16 to 19 & $44(49.5)$ & $81(48.8)$ & 1 & \\
\hline \multicolumn{5}{|l|}{ Education } \\
\hline $8^{\text {th }}$ grade & $39(41.9)$ & $87(52.4)$ & $0.56[0.24-1.32]$ & $2.52[1.02-6.22]^{*}$ \\
\hline $1^{\text {st }}$ year & $13(14.0)$ & $11(6.6)$ & 1 & $2.26[1.21-4.22]^{\star}$ \\
\hline $2^{\text {nd }}$ year & $33(35.5)$ & $36(21.7)$ & $2.64[1.10-6.40]^{*}$ & \\
\hline $3^{\text {rd }}$ year & $8(8.6)$ & $32(19.3)$ & $2.05[1.12-3.74]^{\star}$ & \\
\hline \multicolumn{5}{|l|}{ Socioeconomic level } \\
\hline Up to $2 \mathrm{MW}$ & $46(50.0)$ & $73(46.0)$ & $0.84[0.51-1.42]$ & \\
\hline Above $2 \mathrm{MW}$ & $46(50.0)$ & $86(54.0)$ & 1 & \\
\hline
\end{tabular}


Table 4. Association of independent variables and presence and absence o cervical and shoulder girdle pain among adolescents continuation

\begin{tabular}{|c|c|c|c|c|}
\hline Independent variables & $\begin{array}{c}\text { Presence of pain } \\
\mathrm{n}(\%)\end{array}$ & $\begin{array}{c}\text { Absence of pain } \\
\mathrm{n}(\%)\end{array}$ & OR [Cl 95\%] & Adusted OR [CI 95\%] \\
\hline $\begin{array}{l}\text { Professional activity } \\
\text { Works } \\
\text { Does not work }\end{array}$ & $\begin{array}{l}33(35.5) \\
60(64.5)\end{array}$ & $\begin{array}{c}55(33.1) \\
111(66.9)\end{array}$ & $\begin{array}{c}0.90[0.53-1.54] \\
1\end{array}$ & \\
\hline $\begin{array}{l}\text { Nutritional status } \\
\text { Overweight/obesity } \\
\text { Eutrophic }\end{array}$ & $\begin{array}{l}63(67.0) \\
31(33.0)\end{array}$ & $\begin{array}{l}129(77.7) \\
37(22.3)\end{array}$ & $\begin{array}{c}1.72[0.98-3.02] \\
1\end{array}$ & \\
\hline $\begin{array}{l}\text { Computer use } \\
\text { High time }(>3 \mathrm{~h} / \text { day }) \\
\text { Low time }(<3 \mathrm{~h} / \text { day })\end{array}$ & $\begin{array}{l}57(60.6) \\
37(39.4)\end{array}$ & $\begin{array}{l}92(55.4) \\
74(44.6)\end{array}$ & $\begin{array}{c}0.81[0.48-1.35] \\
1\end{array}$ & \\
\hline $\begin{array}{l}\text { Videogame use } \\
\text { High time }(>1 \mathrm{~h} / \text { day }) \\
\text { Low time }(<1 \mathrm{~h} / \text { day })\end{array}$ & $\begin{array}{l}33(35.1) \\
61(64.9)\end{array}$ & $\begin{array}{c}63(38.0) \\
103(62.0)\end{array}$ & $\begin{array}{c}1.13[0.67-1.92] \\
1\end{array}$ & \\
\hline
\end{tabular}

Table 5. Association of independent variables and the presence and absence of thoracic and lumbar pain among adolescents

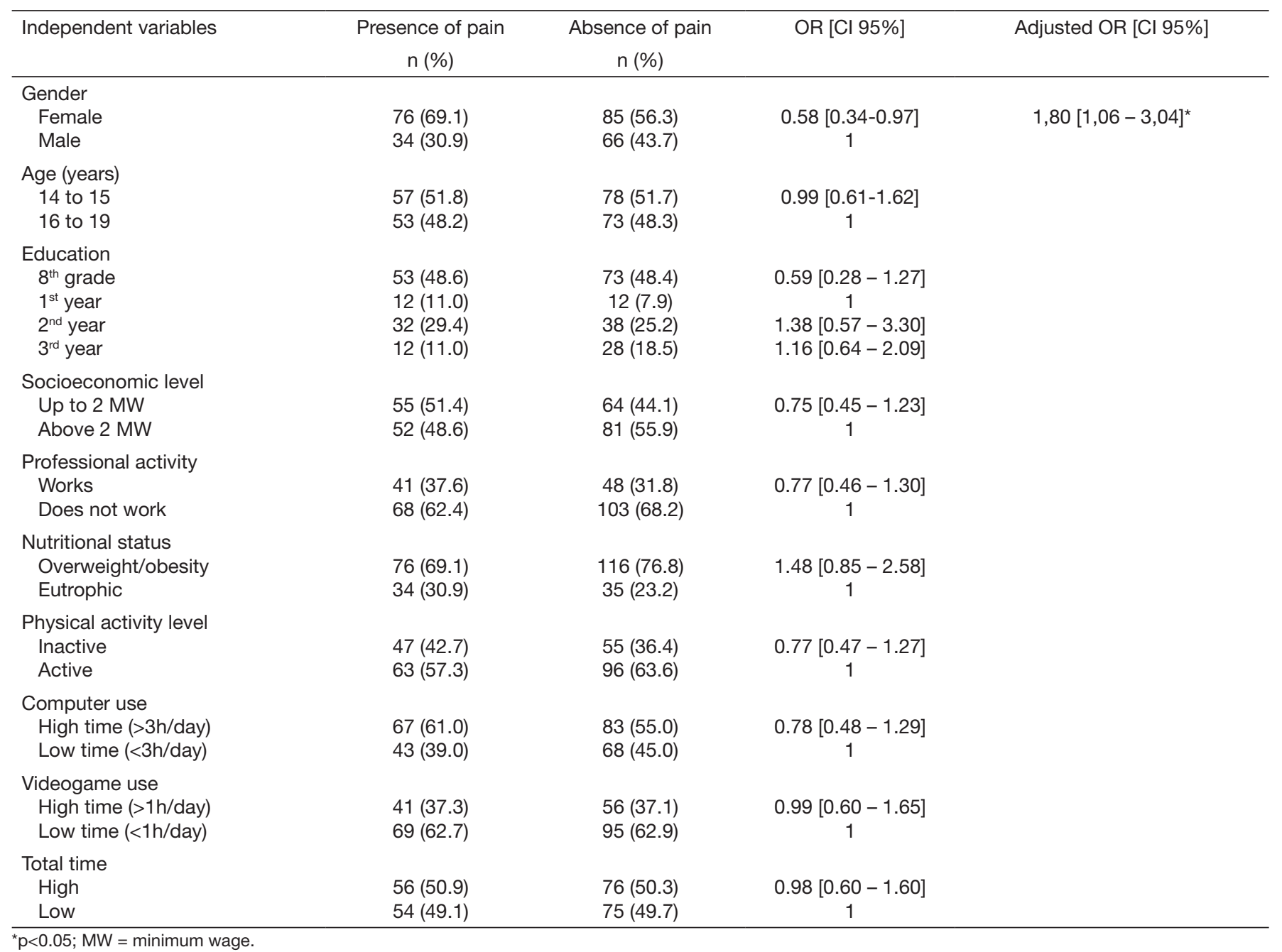


Table 6. Association of independent variables and presence and absence of upper and lower limb pain among adolescents

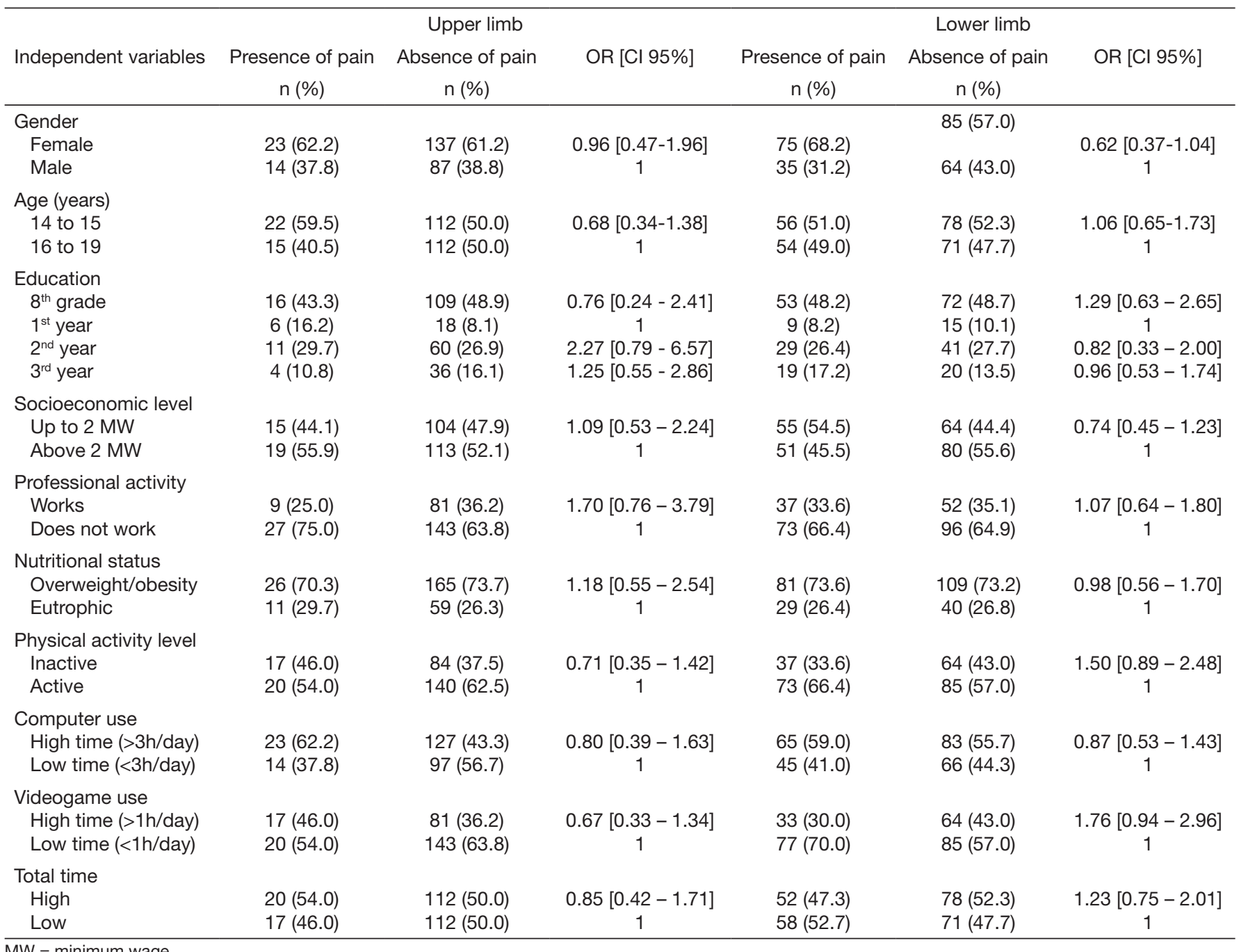

\section{DISCUSSION}

This study was encouraged by the lack of Brazilian studies evaluating musculoskeletal pain prevalence in adolescents and its possible association with the use of computers and videogames. There has been high prevalence $(72.1 \%)$ of musculoskeletal complaints, especially among females. Lower rates $(4-40 \%)$ were found in a systematic review ${ }^{18}$, and its authors justify that such disparity is due to methodological and sample criteria of evaluated studies.

However, a previous study ${ }^{9}$ with adolescents of a private school of São Paulo, using similar methodological procedure as our study, has observed $39.4 \%$ prevalence of musculoskeletal complaints. It is believed that the difference in prevalence might be justified by issues regarding type of teaching (public and private), which directly impacts socioeconomic status, by regional issues (Brazilian Northeastern and Southeastern regions), by the type of questionnaire (associated or not to the use of electronic devices) and by temporal analysis of answers (pain in the last 3 months and in the last 6 months). In addition, possible lifestyle changes along the years seem to influence results, fact which reinforces the importance of such investigation about factors associated to this problem, making indispensable the evaluation and total health attention for such individuals.

With regard to gender, it was observed that the prevalence of musculoskeletal pain among adolescents was significantly higher (78.9\%) among females as compared to males (61.4\%) with pain complaint likelihood 10.66 higher for females. Confirming this finding, other studies ${ }^{3,6,9,18}$ have also observed that musculoskeletal pain was more common among girls. However, factors which may influence this difference between genders in the prevalence of musculoskeletal pain are still not fully defined ${ }^{18}$.

It is argued that such issue could be explained by social and educational aspects, since females in general are more attentive to health-related issues and as a consequence would more frequently report possible complaints or symptoms. In addition, the presence of hormonal changes in girls during puberty may influence results ${ }^{19}$. On the other hand, Costigan et al. $^{20}$ have reported that girls have lower physical activity levels and longer time spent with sedentary behaviors 
which, associated to described factors, negatively contribute to different health indicators, including musculoskeletal pain complaints.

Our study has observed mean computer use of 3.83 hours/ day and total time of 4.69 hours/day. In the literature, values used as reference points to characterize long electronic devices use time vary between 2 and 5 hours/day ${ }^{21}$. With this, it may be inferred that time spent with computers and total use time found among evaluated adolescents are high. According to previous studies, total time spent by adolescents during one week using computers may vary from 80 to $840 \mathrm{~min}^{1,2}$, which confirms our study results.

This variation might be explained by the level of technological and economic development of a certain country or region. In this sense, excessive hours using such equipment by the studied sample, are possibly due to a higher number of activities which may be performed by means of electronic devices, as well as to broader availability of such equipment in the most different places ${ }^{21}$. Furthermore, this result might be a reflex of the program implemented by the State Department of Education, which has distributed such equipment to all high school students of public schools and has contributed for increased access to this technology, otherwise available only to families with higher socioeconomic levels ${ }^{2}$. The number of hours spent by adolescents of this study translates the excessive use of such devices and may be a warning sign for possible pain complaints.

The grade attended by adolescents was a relevant factor to trigger musculoskeletal pain. This study has identified that students of the $8^{\text {th }}$ grade had lower possibilities of pain complaints $(\mathrm{OR}=0.41)$ and those attending the $2^{\text {nd }}$ and $3^{\text {rd }}$ year of high school had, respectively, 2.52 and 2.56 more probabilities of reporting cervical and shoulder girdle pain. Such result might be due to the fact that students are preparing for college entrance examination, with high levels of stress due to professional choice issues, which may increase the likelihood of pain onset, especially musculoskeletal pain ${ }^{22}$.

Finally, there has been no association between musculoskeletal pain and the use of computers and videogames. This result is different from the international literature ${ }^{10-12}$, but confirms a Brazilian study'. Such findings portray the reality of two States of a still developing country. In developed countries, it is evident that time using electronic devices is very high and increases the risk for musculoskeletal pain ${ }^{3,5}$. Notwithstanding our results, this study has evaluated just one public school of a city in the countryside of Pernambuco, restricting both generalization of results to public school students and the extrapolation to private school students. In addition, the self-applied questionnaire may admit memory bias of respondents, over or undervaluing their answers.

Longitudinal studies, based on representative samples, with public and/or private school students, may offer significant contributions for the study of the relationship between the use of electronic devices and musculoskeletal pain. In spite of the limitations of this study, results found are a warning sign for possible pain onset based on adolescents' gender and age.
Our results suggest the follow up of adolescents excessively using such devices, to decrease as much as possible negative repercussions related to this use.

\section{CONCLUSION}

Our results have evidenced high prevalence of musculoskeletal pain among adolescents, especially among females. In spite of the excessive use of computers and videogames, it was not possible to observe associations with musculoskeletal pain. It was only observed that pain is associated to gender and to the attended grade, being that females and students of the last school years are more exposed to musculoskeletal pain risks.

\section{REFERENCES}

1. Hakala P, Rimpelä A, Salminen JJ, Virtanen SM, Rimpelä M. Back, neck and shoulder pain in Finish adolescentes: national cross sectional surveys. BMJ. 2002;325(7363):743-5.

2. Silva CA, Zapata, AL, Moraes AJ, Doria Filho U, Leon C. Utilização do computador e de jogos eletrônicos e avaliaçáo da ergonomia com uso do computador em adolescentes de uma escola privada na cidade de São Paulo. Rev Paul Pediatr. 2006;24(2):104-10.

3. Hakala PT, Saarni LA, Punamäki RL, Wallenius MA, Nygard CH, Rimpelä AH. Musculoskeletal symptoms and computer use among Finnish adolescentes--pain intensity and inconvenience to everyday life: a cross-sectional study. BMC Musculoskelet Dis. 2012;13:41.

4. Milde-Busch A, von Kries R, Thomas S, Heinrich S, Straube A, Radon K. The association between use of electronic media and prevalence of headache in adolescents: results from a population-based cross-sectional study. BMC Neurol. 2010;10:12.

5. Hakala PT, Rimpelä AH, Saarni LA, Salminen JJ. Frequent computer-related activities increase the risk of neck-shoulder and low back pain in adolescents. Eur J Public Health. 2006;16(5):536-41.

6. Punamäki RL, Wallenius M, Nygård CH, Saarni L, Rimpelä A. Use of information and communication technology (ICT) and perceived health in adolescence: the role of sleeping habits and waking-time tiredness. J Adolesc. 2007;30(4):569-85.

7. Van den Bulck J. Television viewing, computer game playing, and Internet use and self-reported time to bed and time out of bed in secondary-school children. Sleep. 2004;7(1):101-4.

8. Anderson CA, Bushman BJ. Effects of violent video games on aggressive behavior, aggressive cognition, aggressive affect, psychological arousal and prosocial behavior: a meta-analytic review of the scientific literature. Psychol. Sci. 2001;12(5):353-9.

9. Zapata AL, Moraes AJ, Leone C, Doria-Filho U, Silva CA. Pain and musculoskeleta pain syndromes related to computer and video game use in adolescents. Eur J Pediatr. 2006;165(6):408-14.

10. Boström M, Dellve L, Thomée S, Hagberg M. Risk factors for generally reduced productivity--a prospecyive cohort study of young adults with neck or upper-extremity musculoskeletal symptoms. Scand J Work Environ Health. 2008;34(2):120-32.

11. Smith L, Louw Q, Crous L, Grimmer-Somers K. Prevalence of neck pain and headaches: impact of computer use and other associative factors. Cephalgia. 2009;29(2):250-7.

12. Jacobs K, Hudak S, McGiffert J. Computer-related posture and musculoskeletal discomfort in middle school students. Work. 2009;32(3):275-83.

13. Abramson JH. WINPEPI (PEPI-for-Windows): computer programs for epidemiologists Epidemiol Perspect Innov. 2004;1(1):1-6

14. Jannini SN, Dória-Filho U, Damiani D, Silva CA. [Musculoskeletal pain in obese adolescents]. J Pediatr. 2011;87(4):329-35. English, Portuguese.

15. Matsudo S, Araújo T, Matsudo V, Andrade E, Oliveira LC, Braggion G. Questionário internacional de atividade física (IPAC): estudo de validade e reprodutibilidade no Brasil. Rev Bras Ativ Fís Saúde. 2001;6(2):8-18.

16. Marfell-Jones M, Olds T, Stewart A, Carter L. International standards for anthropometric assessment. Potchefstroom, South Africa, ISAK, 2006.

17. Cole TJ, Bellizzi MC, Flegal KM, Dietz WH. Establishing a standard definition for child overweight and obesity worldwide: international survey. BMJ. 2000;320(7244):1240-3.

18. King S, Chambers CT, Huquet A, Macnevin RC, Mcgrath PJ, Parker L, Macdonald AJ The epidemiology of chronic pain in children and adolescents revisited: a systematic review. Pain. 2011;152(12):2729-38.

19. Shan Z, Deng G, Li J, Li Y, Zhang Y, Zhao Q. Correlational analysis of neck/shoulder pain and low back pain with the use of digital products, physical activity and psychological status among adolescents in Shanghai. PLoS One. 2013;8(10):e78109.

20. Costigan, SA, Barnett L, Plotnikoff RC, Lubans DR. The health indicators associated with screen-based sedentary behavior among adolescent girls: a systematic review. J Adolesc $\mathrm{He}-$ alth. 2013;52(4):382-92.

21. Barbosa Filho VC, De Campos W, Lopes Ada S. Epidemiology of physical inactivity, sedentary behaviors, and unhealthy eating habits among Brazilian adolescents: a systematic review. Ciênc Saude Colet. 2014;19(1):173-93.

22. Eustáquio E, Cassimiro. Frequência do uso de psicofármacos entre jovens estudantes que cursam pré-vestibular. Adolesc Saúde. 2012;9(4):27-36. 